\title{
Students' Perceptions of the Physics-Mathematical E-Module on Partial Differential Material Based on Gender
}

\author{
Astalini ${ }^{*}$, Darmaji2 ${ }^{2}$, Dwi Agus Kurniawan ${ }^{3}$, Mashelin Wulandari ${ }^{4}$ iD \\ 1,2,3,4 Universitas Jambi, Jambi, Indonesia \\ *Corresponding author: dwiagus.k@unja.ac.id
}

\begin{abstract}
Some obstacles in teaching and learning activities could be seen in the lack of teaching materials that students could easily understand. This is because the main books used are books in English as a whole. Therefore, the researcher developed an electronic book, namely the e-module of mathematical physics I on partial differential material created using 3D Page Flip Professional application. The type of research used is a comparative type of quantitative research. The population in this study were students of Physics education class 2019 with a sample of 80 regular classes A and B. The sampling technique used is simple random sampling. The data were analysed by descriptive and inferential statistics using IBM SPSS Statistic 25 application consisting of descriptive test, normality test, homogeneity test, and t-test. In the assumption test, the data is normally distributed and homogeneous so that a t-test can be performed. The t-test obtained a sig value of 0,043 for gender differences in class A and 0,010 for gender differences in class B. Therefore, it can be concluded that Ho is rejected and $\mathrm{Ha}$ is accepted, meaning that there are significant (significant) differences in perceptions based on gender in each class A and B. Meanwhile, the perception of female students is higher than the perception of male students, but overall students gave a good perception of the mathematics physics e-module on partial differential material.
\end{abstract}

Keywords: Mathematical Physics, Perception, E-Module, Gender

$\begin{array}{ll}\text { History: } & \\ \text { Received } & \text { : June 12, } 2021 \\ \text { Revised } & \text { : June 15, } 2021 \\ \text { Accepted } & \text { : September 25, } 2021 \\ \text { Published } & \text { : October 25, } 2021\end{array}$

\section{INTRODUCTION}

The development of times has changed many things to provide new challenges for humans. As in the 21 st century which is a big challenge in the world of education, where education has an important role in human life (Astalini et al., 2018; Syafrijal \& Desyandri, 2019). Education is needed by students to achieve their goals because education help students to develop their potential to produce good quality human resources and to meet their needs. In this case, a developed country can be seen from the quality of education (Astalini, Kurniawan, \& Putri, 2018; Diani \& Hartati, 2018; Astalini et al., 2019). In line with the 4.0 era, changes in the world of education are growing rapidly to encourage creativity and high competitiveness and demand modern education management (Yayang, 2019). Therefore, the world of education needs to be prepared to face all its development, such as through technology.

Technological developments are very influential in the world of education. The development of technology is increasing rapidly, making everything in the world of education easier and various innovations can be made to meet the learning needs of students and can be accessed via the internet (Khasawneh et al., 2016). It can be said that the development of technology (ICT) is very rapid in the field of education, with the emergence of technology-based activities such as e-commerce, e-government, e-medicine, e-laboratory, and digital-based e-education (Syahrowardi \& Permana, 2016; Diani \& Hartati, 2018). Utilization technology as digital hardware and software is used to improve the effectiveness, efficiency, and attractiveness of learning through e-learning where the dissemination of 
information can be easily reached by everyone (Wardoyo \& Article, 2016). So that e-learning can be used as an alternative to optimizing technological developments.

E-learning is a platform that can support the learning process. E-learning appears to meet the challenges posed by the development of information technology that offers a new way in the world of education for greater access and can improve students' communication skills (Aldhafeeri et al., 2006; Greenhow et al., 2009; Augustine, 2016). This e-learning provides innovation for teachers, where teachers act as facilitators and students as knowledge constructors who can learn anytime and anywhere (Maudiarti, 2018; Sadikin \& Hakim, 2019). Many educational institutions have implemented e-learning with various applications, but success in learning is not only determined by human resource factors but also the selection of models, methods, strategies, to the selection of teaching materials (Andani, 2020; Fatkhiyani \& Dewi, 2020; Febliza \& Okatariani, 2020). Many teaching materials can be used, one of them is an e-module.

Teaching materials are a set of learning tools that are important in helping students learn a particular material (Irawati \& Saifuddin, 2018; Rismaningtyas, Slamet, Kurniawati, \& Pranoto, 2019; Syafrijal \& Desyandri, 2019). The teaching materials used must be chosen appropriately, well, and interestingly, such as in the form of soft files so that they can facilitate learning and help students achieve the expected competencies (Rizki \& Linuhung, 2016). Modules that are in line with times are electronic-based modules or e-modules that aim to enable students to study independently (Sofyan, Angereini, \& Saadiah, 2019; Ilmi, Arnawa, Yerizon, \& Bakar, 2021). Therefore, the module used must meet the requirements and be attractive. In this study, researchers used a flipbook-based e-module using a professional 3D page flip on mathematical physics material, namely partial derivatives.

Mathematical physics is a combination of physics and mathematics subjects and is considered a compulsory subject for students of physics education at the University of Jambi (Yanti, Trisna, Usmeldi, \& Ramli, 2016). The topics discussed are related to advanced courses such as mechanics, modern physics, etc., which contain a description of the problem and how to solve it (Saputri, Fadilah, \& Wahyudi, 2016; Cape, 2018; Bustami, Ngadimin, \& Farhan, 2020). So far, the study program only relied on the book Mathematical Methods in the Physical Sciences written by Mary L. Boas as the main book for the Mathematics Physics I course which uses English, making it quite difficult for the students to understand. Whereas the use of teaching materials acts as a tool and in improving the quality of learning so that the materials and concepts are conveyed properly, the improvement in quality or quality itself can be measured by looking at students' perceptions of the e-modules made (Pathoni, Jufrida, Saoutri, \& Sari, 2017; Jazuli, Azizah, \& Meita, 2018; Darmaji, Astalini, \& Kurniawan, 2019). Perception is someone's perspective through the process of the five senses to achieve awareness and requires certain items in understanding information (Sickle, 2016; Qiong, 2017; Yunita \& Maisarah, 2020). This perception is carried out to find out how students view the e-module of mathematics physics I on partial differential material using 3D page flip professional software. 3D page flip professional software is an application used to create flipbooks or e-books, e-papers, e-magazines, etc., which can be published in various formats (Bakri, Siahaan, \& Permana, 2016). This perception will also look at perceptions based on gender differences, where gender differences are the differences in characteristics, traits, and ways of thinking between males and females (Desiningrum, 2015; Anggoro, 2016). Therefore, gender can be a factor that distinguishes perceptions between students.

The relevant research stated that e-module provides convenience for students, but the resulting e-module cannot be displayed in 3D (Pratono et al., 2018; Triwahyuningtyas et al., 2020). The use of e-modules can provide benefits to students (Nisa et al., 2020; Pathoni et al., 2017). Based on the research that has been done, none of them discusses flipbook-based emodules in mathematics physics courses on partial differential material and perceptions of e- 
modules based on gender. Therefore, the researchers tried to research gender-based perceptions of the physics-mathematical e-module. Based on the description above, there are several objectives of this study, namely to determine the perceptions of students in class $\mathrm{A}$ and $\mathrm{B}$, to determine the differences in student perceptions based on gender differences in both class A and class B on the E-Module of Mathematics Physics on partial differential material.

\section{METHODS}

The type of research used is quantitative research with a comparative type. Quantitative research is a type of research that produces data in form of numbers about a phenomenon and analyses the data using statistical data (Hendri, Pramudya, Ika, \& Pratiwi, 2020). Comparative research is used to compare two or more research variables. In addition, this study was used to see student perceptions in which the data came from questionnaires, about the students' assessments for the e-modules made by the researchers (Pathoni et al., 2017; Darmaji, Kurniawan, et al., 2019). The data collection instrument used in this study was a questionnaire. A questionnaire is an evaluation tool that contains several questions/statements that must be filled out by the respondents to obtain information (Irwansyah, Lubab, Farida, \& Ramdhani, 2017). This questionnaire uses the Likert scale 4. The Likert scale is a rating scale developed by Likert to measure something systematically and consists of four or more answer choices (Joshi, Kale, Chandel, \& Pal, 2015). Likert scale (1-4) is designed to measure the perception of a person or group of people where a score of 1 to 4 is divided into 1 (not very good), 2 (not good), 3 (good), and 4 (very good) (Darmaji, Kurniawan, et al., 2019; Pranatawijaya \& Priscilla, 2019). The grid of students' perception questionnaire instruments is shown in Table 1 below. Table 1 shows the student perception questionnaire grid consisting of three variables, namely appearance, material, and benefits, with 10 indicators and 15 positive statements.

Table 1. Student perception questionnaire

\begin{tabular}{cl}
\hline Variable & \multicolumn{1}{c}{ Indicator } \\
\hline Display & 1. Text clarity \\
e-module & 2. Clarity of images, animations, videos, and simulations \\
& 3. Draw pictures, animations, videos, and simulations \\
E-module material & 1. Presentation of material \\
& 2. Clarity of sentences \\
& 3. The suitability of the sample with the material \\
Benefits of e- & 1. Euitability of images, animations, videos, and simulations \\
modules & 2. Interest in using e-modules \\
& 3. Increased learning motivation \\
\hline
\end{tabular}

Table 2. Perception questionnaire quantitative criteria score range

\begin{tabular}{cc}
\hline Range & Criteria \\
\hline $48,76-60,00$ & Very good \\
$37,51-48,75$ & Good \\
$36,36-37,50$ & Not good \\
$15,00-26,25$ & Not very good \\
\hline
\end{tabular}

Table 2 shows the range of students' perception questionnaire scores consisting of 4 ranges and 4 criteria. The target in this study was physics education students batch 2019 FKIP Jambi University who had contracted the mathematics physics course I as the 
population. Population is the entire object under study and has certain characteristics that are important in research (Asiamah, Mensah, \& Oteng-Abayie, 2017; Nasution, 2017). While sample is a part of the population that represents the population but also could represent the data or the target as a whole (Otzen \& Manterola, 2017). The sample used in this study were 80 students from Regular A and B classes consisting of 34 male students and 46 female students. The sampling technique used in this research is simple random sampling. Simple random sampling is a sampling technique that is carried out randomly in the management of the questionnaire (Dewa, Mukin, \& Pandango, 2020; Owusu-Fordjour, Koomson, \& Hanson, 2020).

The data analysis techniques used in this research were comparative analysis and inferential analysis. Comparative data analysis is used to compare perceptions with two or more variables. While statistical inferential data analysis was carried out with non-parametric types, namely t-test or independent sample t-test which used to see the differences in the students' perceptions in class A and B or based on gender differences in each class (Zhu, Srivastava, Ibrahim, Patro, \& Love, 2019). Before the t-test is carried out, an assumption test or prerequisite test is carried out consisting of normality and homogeneity tests (Huda et al., 2020; Suprianto, Ahmadi, \& Suminar, 2019).

The normality test was carried out to see whether the data were normally distributed or not as seen from the significance value. The guideline for decision-making is if the significant value is $<0.05$ the data is not normal and vice versa, if the significance value is > 0.05 the data is normal. The normality test of the data distribution used was the Kolmogorov Smirnov test using SPSS. The homogeneity test of the data was carried out to see the level of homogeneity with the assumption that the data was homogeneous by looking at Levine's Test for Equality of Variance on SPSS software with the test criteria used were sig > with a level of $=0.05$. The $\mathrm{t}$ statistic test shows how far the influence of one independent variable individually in explaining the variation of the dependent variable. The test is carried out using a significance level of $0.05(\mathrm{a}=5 \%)$. Acceptance or rejection of the hypothesis is done with the criteria, if the significant value of $\mathrm{t}<0.05$ then $\mathrm{H} 0$ is rejected, meaning that there is a significant influence between one independent variable on the dependent variable. Meanwhile, if the significant value of $\mathrm{t}>0.05$ then $\mathrm{H} 0$ is accepted, meaning that there is no significant effect between one independent variable on the dependent variable. The research process carried out can be described in the following chart:

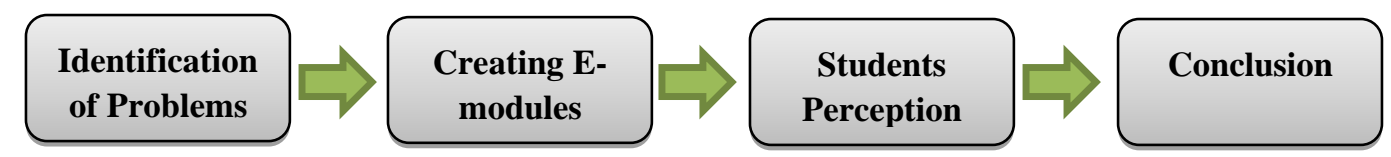

Figure 1. Research flow chart

\section{RESULTS AND DISCUSSION}

\section{Results}

This research was conducted on students of physics education class 2019 specifically the regular classes A and B consisting of 40 students in total. This study aims to see how students perceive the e-module of mathematics physics I based on the Professional 3D Page Flip application on Partial Differential material. This perception was obtained from a questionnaire distributed via a google form. The questionnaire contains 15 positive statements with 4 answer choices, namely strongly agree, agree, disagree, and strongly disagree. The data obtained in the questionnaire were analysed using IBM SPSS Statistic 25 that consisted of the students' perceptions in class A and B, students' perceptions in class A, students' perceptions in class B, students' perceptions in class A based on gender, and 
students' perceptions in class B based on gender. The results of data analysis show that the descriptive results of the students' perceptions in class A and B were dominantly in good categories with a percentage of $61,3 \%$ and the acquisition of the mean or average value of 46,51 , the median or mean value of the data 45,50 , mode 42 , the minimum value or the lowest value is 37 , the maximum value or the highest value is 58 , and the standard deviation is 5,816. After the general descriptive test has been conducted, it could be followed by a descriptive test based on class to see the descriptive results in each class.

In class A which consists of 40 students, the results show that most of the students have a perception in the good category with a percentage of $65 \%$ with an average score of 46,55 , a minimum value of 42 , a maximum value of 58 , and a standard deviation of 54,39 . As for class B which also consists of 40 students, the results show that most of the students have perceptions in the good category where the average value is 46,48 , the minimum value is 37 , the maximum value is 57 , and the standard deviation is 6,239 . Overall, the students have a good perception of the developed e-modules. To determine differences in perceptions in A and B classes based on gender, the data were analyzed using inferential statistics. In this inferential statistic, the data is tested based on assumption test and hypothesis test. The assumption test consists of normality test and homogeneity test. While the hypothesis test is done by using t-test. The data were also obtained from a questionnaire that was analyzed using IBM SPSS Statistics 25.

If the prerequisite test has been done, it can be continued with hypothesis testing. The hypothesis test used is t-test (independent sample t-test) for both classes. Independent sample $\mathrm{t}$-test or t-test is part of parametric inferential statistics. This test is carried out to see whether there are differences or comparisons between the two samples or not. The results of t-test in classes $A$ and $B$ showed the significance value is 0,954 . It means that the value of sig $>0,05$ and there is no difference in the average perception of $\mathrm{A}$ and $\mathrm{B}$ classes. To know the differences in perceptions between class A and class B, this study also shows differences in perceptions based on gender in each class. This difference is obtained by performing a t-test. F symbolizes female students and $\mathrm{M}$ symbolizes male students. In class $\mathrm{A}$, the significance value is 0,043 with the average value of female students is 47,96 , while the average value of male students is 44.44, which means there is a significant average difference between students' perceptions of the average value. As for class B, the significance is 0,010 where the average value of female students is 48.73 and the average value of male students is 43,72 , which means there is a significant difference in the average score between female and male students in class B on the physics-mathematical e-module in partial differential material.

This study was conducted to see the perceptions of students of physics education class 2019 in class A and B by conducting a descriptive test to see the descriptive results of perceptions and a t-test to see whether there were differences in student perceptions or not based on gender. The descriptive test for the students' perceptions in class A and B was carried out with 80 students as the sample, consisting of 40 students of class A and 40 students of class B. The results of the descriptive test found that $6,3 \%$ (5 students) stated that the e-module is not good, 61,3\% (49 students) stated that the e-module is good, and 32,5\% (26 students) stated that this e-module is in the very good category. In addition, the statistical distribution consist of mean, median, mode, minimum, maximum, and standard deviation shows that the mean or average value is 46,51 , the median or mean value of the data is 45,50 , the mode is 42 , the minimum or lowest value is 37 , the maximum or highest value is 58 , and the standard deviation is 5,816. Overall, the students have a good perception of the developed e-modules.

To conduct a general perception analysis, a descriptive analysis of perceptions was also conducted in class A and B. In class A, 5\% (2 students) stated that the e-module is not good, $65 \%$ (26 students) stated that the e-module is good, and 30\% (12 students) stated that 
the e-module is very good with the mean value of 46,54 , minimum score of 37 , maximum value of 58, and standard deviation of 5,439. As for class B, 7,5\% (3 students) stated that the e-module is not good, $57.5 \%$ (23 students) stated that the e-module is good, and $35 \%$ (14 students) stated that the e-module is very good with the mean value of 46,48 , minimum value of 37 , maximum value of 57 , and standard deviation of 6,239. Overall, the students have a good perception of the developed e-module.

\section{Discussion}

Perception is someone's perspective in understanding information consciously (Sickle, 2016; Qiong, 2017; Yunita \& Maisarah, 2020). This perception was carried out to see how the perceptions of students in grades A and B, as well as the differences in perceptions between classes $\mathrm{A}$ and $\mathrm{B}$ based on gender, namely male and female, on the physics-mathematical e-module that had been made. The advantage of the developed emodule is it uses an electronic format that can be displayed using electronic devices or special software so it is more practical to carry and use anywhere and anytime. After conducting a descriptive test in each class, then an analysis of the differences in perceptions in class A and B and each class was carried out based on gender differences. To obtain information about perceptions based on gender differences, assumption tests and hypothesis tests were carried out. This assumption test is carried out as a condition for testing the hypothesis which consists of normality and homogeneity tests (Nurvianti \& Syarkowi, 2018; Suprianto et al., 2019).

Gender is a characteristic that is placed on males and females so that it can cause different perceptions. Meanwhile, gender differences are differences in characteristics, traits, and ways of thinking between males and females (Desiningrum, 2015; Anggoro, 2016). Based on the results of the research conducted, it is found that the average perception of female students was higher than the perception of male students because female students tend to judge things based on stimuli that are influenced by various factors. Based on the results of research conducted, differences in student perceptions could be seen from the average value.

In conclusion, this study provides an overview of students' perceptions toward the mathematical physics e-module on partial differential material in which most of the students stated that the e-module is good and feasible to use. This perception is necessary because it has an impact on the continuity of the learning process. The results of this perception are expected to be able to help students understand mathematics physics material and pass this course because the e-modules made are packaged in Indonesian, which is easy to understand. In addition, it is hoped that students can prepare themselves to improve their pedagogic abilities as future lecturers, especially in physics subjects or mathematics physics courses. This research is limited to the students' perceptions of the developed e-modules.

\section{CONCLUSION}

Based on the results of this research, it is found that there is no different perception between the students in the two classes. However, there are significant differences between female and male students in each class. Therefore, gender can be said as one of the factors that influence differences in perception.

\section{REFERENCES}

Aldhafeeri, F., Almulla, M., \& Alraqas, B. (2006). Teachers' expectations of the impact of Elearning on Kuwait's public education system. Social Behavior and Personality, 34(6), 711-728. https://doi.org/10.2224/sbp.2006.34.6.711. 
Andani, M. (2020). E-Modul Fisika Dasar I Berbasis 3D Pageflip Professional. Schrodinger Journal of Physics Education, 1(2), 44-47. https://doi.org/10.37251/sjpe.v1i2.79.

Anggoro, B. S. (2016). Analisis Persepsi Siswa SMP terhadap Pembelajaran Matematika ditinjau dari Perbedaan Gender dan Disposisi Berpikir Kreatif Matematis. Al-Jabar: Jurnal Pendidikan Matematika, 7(2), 153-166. https://doi.org/10.24042/ajpm.v7i2.30.

Asiamah, N., Mensah, H. K., \& Oteng-Abayie, E. F. (2017). General, target, and accessible population: Demystifying the concepts for effective sampling. Qualitative Report, 22(6), 1607-1621. https://doi.org/10.46743/2160-3715/2017.2674.

Astalini, A., Kurniawan, D. A., \& Putri, A. D. (2018). Identifikasi Sikap Implikasi Sosial dari IPA, Ketertarikan Menambah Waktu Belajar IPA, dan Ketertarikan Berkarir Dibidang IPA Siswa SMP Se-Kabupaten Muaro Jambi. Jurnal Tarbiyah: Jurnal Ilmiah Kependidikan, 7(2), 93-108. https://doi.org/10.18592/tarbiyah.v7i2.2142.

Astalini, Darmaji, Kurniawan, D. A., Sumaryanti, Perdana, R., \& Susbiyanto. (2019). Relationship Between Students Interests and Attitudes in Physical Subject. Journal of Educational Science and Technology, 5(3), 202-211. https://doi.org/10.26858/est.v5i3.9309.

Bakri, F., Siahaan, B. Z., \& Permana, A. H. (2016). Rancangan Website Pembelajaran Terintegrasi dengan Modul Digital Fisika Menggunakan 3D PageFlip Professional. Jurnal Penelitian \& Pengembangan Pendidikan Fisika, 2(2), 113-118. https://doi.org/10.21009/1.02215.

Bustami, Ngadimin, \& Farhan, A. (2020). The Difficulty Factors of Students to Understand Mathematics Physics 1 at Physics Education Department FKIP Unsyiah. Asian Journal of Science Education, 2(1), 1-10. https://doi.org/10.24815/ajse.v2i1.14725.

Darmaji, Astalini, \& Kurniawan, D. A. (2019). E-Module Based Problem Solving in Basic Physics Practicum for Science Process Skills. IJOE, 15(15), 4-17. https://onlinejournals.org/index.php/i-joe/article/view/10942.

Darmaji, D., Kurniawan, D. A., Astalini, A., Kurniawan, W., Anwar, K., \& Lumbantoruan, A. (2019). Students' perceptions of electronic's module in physics practicum. Journal of Education and Learning (EduLearn), 13(2), 288-294. https://doi.org/10.11591/edulearn.v13i2.13005.

Desiningrum, D. R. (2015). Kesejahteraan Psikologis Lansia Janda/Duda Ditinjau dari Persepsi Terhadap Dukungan Sosial dan Gender. Jurnal Psikologi Undip, 13(2), 102106. https://doi.org/10.14710/jpu.13.2.102-201

Dewa, E., Maria Ursula Jawa Mukin, \& Oktavina Pandango. (2020). Pengaruh Pembelajaran Daring Berbantuan Laboratorium Virtual Terhadap Minat dan Hasil Belajar Kognitif Fisika. JARTIKA Jurnal Riset Teknologi Dan Inovasi Pendidikan, 3(2), 351-359. https://doi.org/10.36765/jartika.v3i2.288.

Diani, R., Hartati, N. S., \& Email, C. A. (2018). Flipbook berbasis literasi Islam: Pengembangan media pembelajaran fisika dengan 3D pageflip professional. Flipbook Berbasis Literasi Islam: Pengembangan Media Pembelajaran Fisika Dengan 3D Pageflip Professional, 4(2), 234-244. https://doi.org/10.21831/jipi.v4i2.20819.

Etikan, I. (2017). Sampling and Sampling Methods. Biometrics \& Biostatistics International Journal, 5(6), 215-217. https://doi.org/10.15406/bbij.2017.05.00149.

Fatkhiyani, K., \& Dewi, R. A. K. (2020). The development of the textbook of basical science concept contained ethnoscience. Jurnal Prima Edukasia, 8(2), 156-165. https://doi.org/10.21831/jpe.v8i2.32237.

Febliza, A., \& Okatariani, O. (2020). The Development of Online Learning Media by Using Moodle for General Chemistry Subject. Journal of Educational Science and Technology (EST), 6(1), 40. https://doi.org/10.26858/est.v6i1.12339. 
Greenhow, C., Robelia, B., \& Hughes, J. E. (2009). Learning, teaching, and scholarship in a digital age: Web 2.0 and classroom research: What path should we take now? Educational Researcher, 38(4), 246-259. https://doi.org/10.3102/0013189X09336671.

Hendri, M., Pramudya, L., Ika, N., \& Pratiwi, S. (2020). Analisis hubungan karakter semangat kebangsaan dengan hasil belajar siswa. Jurnal Pembangunan Dan Pendidikan: Fondasi Dan Aplikasi, 7(1), 1-8. http://dx.doi.org/ 10.21831/jppfa.v7i1.25209.

Huda, S., Yasin, M., Fitri, A., Syazali, M., Supriadi, N., Umam, R., \& Jermsittiparsert, K. (2020). Numerical Ability Analysis: The Impact of the Two Stay-Two Stray Learning Model on the Sequence and Series Topic in Islamic Boarding School. Journal of Physics: Conference Series, 1467(1). https://doi.org/10.1088/17426596/1467/1/012002.

Ilmi, R., Arnawa, I. M., Yerizon, \& Bakar, N. N. (2021). Development of an Android-Based for Math E-Module by using Adobe Flash Professional CS6 for Grade X Students of Senior High School. Journal of Physics: Conference Series, 1742(1). https://doi.org/10.1088/1742-6596/1742/1/012026.

Irawati, H., \& Saifuddin, M. F. (2018). Analisis Kebutuhan Pengembangan Bahan Ajar Mata Kuliah Pengantar Profesi Guru Biologi Di Pendidikan Biologi Universitas Ahmad Dahlan Yogyakarta. Bio-Pedagogi, 7(2), 96. https://doi.org/10.20961/biopedagogi.v7i2.27636.

Irwansyah, F. S., Lubab, I., Farida, I., \& Ramdhani, M. A. (2017). Designing Interactive Electronic Module in Chemistry Lessons. Journal of Physics: Conference Series, 895(1). https://doi.org/10.1088/1742-6596/895/1/012009.

Jazuli, M., Azizah, L. F., \& Meita, N. M. (2018). Pengembangan Bahan Ajar Elektronik Berbasis Android Sebagai Media Interaktif. LENSA (Lentera Sains): Jurnal Pendidikan IPA, 7(2), 47-65. https://doi.org/10.24929/lensa.v7i2.22.

Joshi, A., Kale, S., Chandel, S., \& Pal, D. K. (2015). Likert Scale : Explored and Explained. British Journal of Applied Science \& Technology, 7(4), 396-403. https://doi.org/10.9734/BJAST/2015/14975.

Khasawneh, R., Simonsen, K., Snowden, J., Higgins, J., Beck, G., Khasawneh, R., Simonsen, K., Snowden, J., Higgins, J., \& Beck, G. (2016). The Effectiveness of E-Learning in Pediatric Medical Student Education. Medical Education Online, 21(1), 1-3. https://doi.org/10.3402/meo.v21.29516.

Kurniawan, W., Darmaji, D., Astalini, A., Kurniawan, D. A., \& Hidayat, M. (2019). Multimedia physics practicum reflective material based on problem solving for science process skills. International Journal of Evaluation and Research in Education (IJERE), 8(4), 590-595. https://doi.org/10.11591/ijere.v8i4.20258.

Maudiarti, S. (2018). Penerapan E-Learning Di Perguruan Tinggi. Perspektif Ilmu Pendidikan, 32(1), 51-66. https://doi.org/10.21009/pip.321.7.

Nasution, L. M. (2017). Statistik Deskriptif. Jurnal Hikmah, 14(21), 49-55. https://doi.org/10.1021/ja01626a006.

Nisa, W. L., Ismet, I., \& Andriani, N. (2020). Development of E-Modules Based on Multirepresentations in Solid-State Physics Introductory Subject. Berkala Ilmiah Pendidikan Fisika, 8(2), 73. https://doi.org/10.20527/bipf.v8i1.7690.

Nurvianti, I., \& Syarkowi, A. (2018). Penggunaan Komik pada Pembelajaran Fluida Statis di Kelas XI IPA SMA Negeri 2 Kota Jambi Tahun 2017. Jurnal Penelitian Pembelajaran Fisika, 9(1), 59-65. https://doi.org/10.26877/jp2f.v9i1.2124.

Otzen, T., \& Manterola, C. (2017). Técnicas de Muestreo sobre una Población a Estudio. International Journal of Morphology, 35(1), 227-232. https://doi.org/10.4067/S0717- 


\section{7.}

Owusu-Fordjour, C., Koomson, C. K., \& Hanson, D. (2020). The Impact of Covid-19 on Learning-The Perspective of the Ghanaian Student. European Journal of Education Studies, 7(3), 88-101. https://doi.org/10.5281/zenodo.3753586.

Pathoni, H., Jufrida, Saputri, I., \& Sari, W. (2017). Persepsi Mahasiswa Terhadap E-modul Pembelajaran Mata Kuliah Fisika Atom dan Inti. Jurnal Eksakta Pendidikan (JEP), 1(1), 55-62. https://doi.org/10.24036/jep/vol1-iss1/35.

Pranatawijaya, V. H., \& Priskila, R. (2019). Pengembangan Aplikasi Kuesioner Survey Berbasis Web Menggunakan Skala Likert dan Guttman. Jurnal Sains Dan Informatika, 5(2), 128-137. https://doi.org/10.34128/jsi.v5i2.185.

Pratono, A., Sumarti, S. S., \& Wijayati, N. (2018). Contribution of Assisted Inquiry Model of E-Module to Students Science Process Skill. Journal of Innovative Science Education, 7(1), 62-68. https://doi.org/10.15294/jise.v7i1.20633.

Qiong, O. (2017). A Brief Introduction to Perception. Studies in Literature and Language, 15(4), 18-28. https://doi.org/10.3968/10055.

Rismaningtyas, A., Slamet, A., Kurniawati, Y., \& Pranoto, S. (2019). Implementation of Contextual Based Teaching Materials on Various Work Themes of Primary School Students. Journal of Primary Education, 8(4), 110-119. https://journal.unnes.ac.id/sju/index.php/jpe/article/view/29113.

Rizki, S., \& Linuhung, N. (2016). Pengembangan Bahan Ajar Program Linear Berbasis Kontekstual dan ICT. Aksioma: Jurnal Pendidikan Matematika FKIP Univ. Muhammadiyah Metro, 5(2), 137-144. http://dx.doi.org/10.24127/ajpm.v5i2.674.

Sadikin, A., \& Hakim, N. (2019). Pengembangan Media E-Learning Interaktif Dalam Menyongsong Revolusi Industri 4.0 Pada Materi Ekosistem Untuk Siswa SMA. Biodik, 5(2), 131-138. https://doi.org/10.22437/bio.v5i2.7590.

Saputri, D. F., Fadilah, S., \& Wahyudi. (2016). Efektifitas Penggunaan Buku Ajar Fisika Matematika Berbasis Inkuiri dalam Perkuliahan Fisika Matematika. Jurnal Penelitian \& Pengembangan Pendidikan Fisika, 2(2), 7-14. https://doi.org/10.21009/1.02202.

Sickle, J. Van. (2016). Discrepancies between student perception and achievement of learning outcomes in a flipped classroom. Journal of the Scholarship of Teaching and Learning, 16(2), 29-38. https://doi.org/10.14434/josotl.v16i2.19216.

Sofyan, H., Anggereini, E., \& Saadiah, J. (2019). Development of E-Modules Based on Local Wisdom in Central Learning Model at Kindergartens in Jambi City. European Journal of Educational Research, 8(4), 1137-1143. https://doi.org/10.12973/eujer.8.4.1137.

Suciyati, \& Mariamah. (2018). Hubungan antara Minat Belajar dengan Hasil Belajar Matematika pada Siswa Kelas V SD Negeri 04 Sila. Jurnal Pendidikan MIPA, 8(2), 142-149. https://doi.org/10.37630/jpm.v8i2.265.

Suprianto, A., Ahmadi, F., \& Suminar, T. (2019). The Development of Mathematics Mobile Learning Media to Improve Students' Autonomous and Learning Outcomes. Journal of Primary Education, 8(1), 84-91. https://journal.unnes.ac.id/sju/index.php/jpe/article/view/19641.

Syafrijal, \& Desyandri. (2019). Deveopment Of Integrated Thematic Teaching Materials With Project Based Learning Models In Class IV of Primary School. International Journal of Educational Dynamics/IJEDS, 1(2), 87-92. https://doi.org/10.24036/ijeds.v1i2.110.

Syahrowardi, S., \& Permana, A. H. (2016). Desain Handout Multimedia Menggunakan 3D Pageflip Professional untuk Media Pembelajaran pada Sistem Android. Jurnal Penelitian \& Pengembangan Pendidikan Fisika, 2(1), 89-96. https://doi.org/10.21009/1.02113. 
Triwahyuningtyas, D., Ningtyas, A. S., \& Rahayu, S. (2020). The problem-based learning emodule of planes using Kvisoft Flipbook Maker for elementary school students. Jurnal Prima Edukasia, 8(2), 199-208. https://doi.org/10.21831/jpe.v8i2.34446.

Wardoyo, C., \& Article, H. (2016). Developing Learning Media Based on E-Learning on Accounting Subject for Senior High School Students. Dinamika Pendidikan Unnes, 11(2), 84-93. https://doi.org/10.15294/dp.v11i2.8932.

Yanti, I. R., Trisna, S., Usmeldi, \& Ramli. (2016). Preminary Research Pengembangan Modul Berbasis Problem Based Instruction pada Mata Kuliah Fisika Matematika di STKIP PGRI Sumatera Barat. E-Journal, 5(1), 19-22. http://journal.unj.ac.id/unj/index.php/prosidingsnf/article/view/3939.

Yayang, E. (2019). Pengembangan E-Modul Berbasis Web Dengan Menggunakan Aplikasi Moodle Pada Mata Kuliah Pengelolaan Perpustakaan. Edutech, 18(1), 25-36. https://doi.org/10.17509/e.v18i1.14113.

Yunita, W., \& Maisarah, I. (2020). Students ' Perception On Learning Language At The Graduate Program OF English Education Amids The Covid 19 Pandemic. Linguists: Journal of Linguistics and Language Teaching, 2069(6), 107-120. http://dx.doi.org/10.29300/ling.v6i2.3718.

Zhu, A., Srivastava, A., Ibrahim, J. G., Patro, R., \& Love, M. I. (2019). Nonparametric expression analysis using inferential replicate counts. Nucleic Acids Research, 47(18), e105. https://doi.org/10.1093/nar/gkz622. 